\title{
Climate policy and the siting of renewable energy projects: towards common but differentiated responsibility at the community level
}

\author{
Dan van der Horst* \\ Edinburgh University
}

\begin{abstract}
Renewable energy receives state support in most western countries, with the aim to reduce fossil fuel use and thus mitigate anthropogenic climate change. Communities may benefit from these subsidies by setting up community-owned renewable energy projects, but to date their overall contribution to UK renewable energy targets has been very small. The most substantive involvement of local people in renewable energy production has been to reduce renewable energy production by resisting wind farm proposals. In response, developers have started to offer benefits to local communities. What is the moral justification of such 'community benefits' from a policy that is already for the common good, and for projects that in general have very few physical effects on people? In this paper I argue that there is a need for a common and spatially explicit justice framework, not just to underpin the siting and development of low carbon energy projects, but also to (simultaneously) engage with other domains of climate policy. I propose some dimensions of such a framework and discuss why its adoption can put the community at the forefront of renewable energy developments; not as passive or reactive 'impacted communities' and not necessarily as out-right owners of energy generation projects, but as proactive local stakeholders involved in the governance of the view, the wind and the greenhouse gas emissions in their area, willing and able to decide what 'common but differentiated responsibilities' should mean at their local level vis a vis national and international duties and obligations in climate and energy policy.
\end{abstract}

Keywords: community, energy, landscape, transitional justice, CBDR.

\section{Introduction}

'Community energy' is a vague term. Walker and Devine-Wright (2008) distinguish between process and outcome for renewable energy projects at the community level. The new UK Community Energy Strategy simply talks of 'many different types of 
p. 223. Climate policy and the siting of renewable energy projects; towards common but differentiated responsibility at the community level

community getting involved in energy issues in many different ways' (DECC, 2014: 2). The Strategy mentions a very broad range of activities, from energy production for sale or self-use in community buildings, to collective bargaining for consumer groups and the adoption of energy efficiency measures and practicing demand reduction through collective action and knowledge sharing.

Local low carbon energy projects can provide genuine benefits to communities of place or interest, but whilst there is a lot to be said for 'small is beautiful' (Shumacher, 1973), it is clearly not enough for our current society; community energy barely registers in terms of renewable energy production or the reduction of energy consumption at the national level and it is difficult to envisage it ever becoming a mayor factor within the current system. The opposite has been the case in the UK; except for remote rural Scotland the contribution of rural communities to renewable energy production has overwhelmingly been negative, due to the many successful local campaigns to reject planning permission for proposed (mainly commercial) windfarms. In order to understand how communities can contribute to our national and international climate change mitigation commitments, we need to look at the role of communities beyond the narrow focus of (partially) self-owned, self-developed community renewable energy projects.

This paper concerns itself with the relationship between local communities and the ethics that are invoked in the local development of renewable energy as part of a wider climate change mitigation policy. The scales of governance for fair climate change adaptation have been discussed elsewhere (Adger, 2001), but there has been insufficient attention for the role, responsibilities and ethical dilemmas of the local in climate change mitigation. What we have seen instead is an iterative progression from top-down siting policies, via siting controversies towards tentative steps to better accommodate local concerns and interests.

Unlike early adopters of renewables like Denmark and Germany, the UK government started the new era of renewables with policies that suited the private sector rather than community groups. This policy choice explains at least in part why local protests against proposed wind farms has been such a recurring and powerful feature of on-shore wind developments in the UK (Pollit, 2010). In response to public resistance companies started to offer various amounts and forms of "community benefits' to try to obtain more local support. This eventually became formal policy with the government specifying that companies should pay $£ 5,000$ a year for every megawatt of energy installed - to support local initiatives. These benefits, paid for by the company receiving government subsidies, were typically used for local social and environmental projects, including energy savings projects. In November 2014, the UK government announced a scheme to encourage commercial wind farm developers to share ownership with local people (BBC, 2014), an idea which had been pioneered in Scotland since $2006 .^{1}$

The definitions of, and boundary between community energy and community benefits from commercial renewable energy projects has thus become blurred. Moreover, the terminology of community benefits ${ }^{2}$ or benefit sharing has been applied to non-renewable energy projects and to the extractive industries generally (and even to industries that extract only knowledge: see Vermeylen, 2007). Media headlines about local responses to the proposed siting of a windfarm or a fracking rig have become remarkably similar in terms of local protests, distinguished mainly (figure 1) by the higher rates which shale gas developers may be offering, whilst windfarm payments are now often labeled a 'bribe' (for discussions of the latter, see Aitken, 2010; Cass et al., 2010). 
p. 224. Climate policy and the siting of renewable energy projects; towards common but differentiated responsibility at the community level

Figure 1: Examples of UK media headlines in relation to community benefits

Fracking: Cuadrilla community benefits could be worth
$£ 6,000$ per household
Cuadrilla says the "lion's share" of up to $£ 800,000$ in community benefits for fracking
could be shared between as few as 130 households
\[ \begin{array}{l}\text { Local councils to receive millions in } \\ \text { business rates from shale gas } \\ \text { developments }\end{array} \]
Acceptable bribery? Local
communities offered $£ 100 \mathrm{k}$ a
year for wind farms
Great green bribe: Say Yes to a windfarm in
your neighbourhood and get $20 \%$ off your
power bill
- Free home improvements could be offered in return for wind farms
- Those living within 1.2miles of Delabole wind farm get a fifth off energy
bills
. Ministers could adopt same approach to new nuclear power plants

How is it possible that in a country where there is so much support for renewable energy (opinion polls show consistent popular support amongst the population at 70 80 per cent), and where disbelief in the scientific evidence of climate remains a minority opinion ${ }^{3}$, the moral underpinning of climate policy is so lost that companies are seen as 'bribing' local communities? And is there a way in which we can disentangle this moral conflict, creating policies that are more morally consistent?

I engage with these questions as follows. First I expose some of the political context that is shaping renewable energy development across national space. I then examine the ethical dimension that underpins international climate policy, focusing especially on the 'principle of common but differentiated responsibility' (CBDR), and what it might mean at the sub-national level. This leads me in turn to explore notions of collective recognition at the landscape level where local communities are facing the possible development of renewable energy projects. I end with a short reflection on what the ethical findings might suggest for policy design.

\section{Politics, geography and techno-economic scale}

The importance of the political context of renewable energy development can be illustrated by looking at Scotland's very different approach to community energy. In comparison to England and Wales, Scotland has seen many more community projects coming to fruition and far lower rejection rates of wind farm planning applications (for a recent overview, see Haggett et al., 2014). But in Scotland many of the early community owned wind farms were developed on land that was previously owned by large (often absent) landlords, and which was bought up by the local community under financial guarantees and support from the new Scottish Government after the introduction of the Land Reform (Scotland) Act 2003. Set against the highly emotive 
p. 225. Climate policy and the siting of renewable energy projects; towards common but differentiated responsibility at the community level

history of the Highland clearances which saw many Gaelic speaking communities being evicted from their ancestral land, community buy out was an iconic policy to address the legacy of feudal land ownership. Around the same time community energy schemes were introduced as a new 'rural development' opportunity for economically fragile Highland communities (van der Horst, 2008). Those communities who succeeded in the land buy-out had the assets and institutional structure to benefit most of this opportunity. It took the best part of a decade for Scotland's pro-community model to be emulated south of the border, where the Rural Community Energy Fund was established in 2011.

The above illustrates how important the political background is to energy developments. The evolution of the energy system often provides a material reflection of shifting political values: the ideal of universal access to energy expressed by the extension (and often nationalization) of the grid, the neo-liberal ideal expressed by property transfer to the private sector, the inter-generational sustainability ideal expressed through the pursuit of low-carbon energy. The local sustainability ideal, expressed through the pursuit of community energy projects could be seen as the scale at which these ideals may potentially be reconciled: The local scale and community ownership implies that the owners, ${ }^{4}$ beneficiaries and impacted people are part of the same community of place, thus reducing externalities through geographical downscaling. In other words, and assuming that the community is not particularly lacking in social capital and cohesion, negative social and environmental externalities are likely to be limited in scale and more evenly distributed amongst the population, whilst positive benefits are more likely to be locally shared.

However the technological and resource frontiers of energy exploration are shifting away from this finer scale that is affordable for out-right community ownership. There is a growing move towards technologies that can drill deeper or reach higher into the sky, can provide more people with energy (fossil or renewable), but also have much stronger impacts on the area of production. This techno-economic process adds further to the uneven geography of beneficiaries and affected communities.

There is a clear engineering logic to the upscaling of wind turbines; wind speed increases with height and the circular area covered by the blades increases not in a linear but in an exponential manner with increased height of the tower. And yet that is not the only factor determining the trend of upscaling. To see upscaling as some kind of natural evolutionary process is politically naïve; the wind turbine manufacturers must think that it is worthwhile investing significant amounts of R\&D money in larger designs and the financial backers of wind farm development must have trust in government policies that will continue to support upscaling in the longer term. The spectacular growth in renewable energy industry could be seen as a prime example of Green Capitalism, which brings "new spaces of accumulation and novel types of regulation" (Dawson, 2010). Indeed Dawson points at the social movements that are rising to resist this form of capitalism and challenge its morality. But this green capitalism is not spatially ubiquitous.

For renewable energy development in the UK, we can envisage the emergence of a broad spatial division in business models, with new large commercial projects heading off to sea to capture most of the wind, energy and grants, with the 'infilling' of on-shore areas that are hypothetically still available for development, being increasingly left to smaller, more adaptable projects. Whether these are developed by 'traditional' private companies, (existing) local organisations or (new) cooperatives, these land-based projects will have to continue to engage in a moral battle and/or forge relationships with members of local communities, offering 'community benefits' and potentially creating partnerships that contain both commercial and community ownership. In urban landscapes, with their dense and complex patterns of land ownership and 
p. 226. Climate policy and the siting of renewable energy projects; towards common but differentiated responsibility at the community level

access rights and guaranteed local energy demand, we may potentially see the most heterogeneous developments, involving commercial, household, local authority and community projects and combining new generation with retrofit or new built housing stock and with various local measures of demand management.

\section{Common but differentiated responsibility (CBDR), at the local level}

The causes and consequences of anthropogenic climate change are unevenly distributed across space and time, and so are the possible mitigation (and adaptation) options. This uneven distribution complicates the answers as to what we can do about it. To put it bluntly, across the world and all of humanity, we need to do enough, whereby everyone needs to do their 'fair bit'. We already have good technical knowledge about the 'bits' we can be doing and the IPCC is providing us with guidance as to what is 'enough'; the current narrative is to try to keep the global change below $+2{ }^{\circ} \mathrm{C}$ by 2100 . However it is far more complicated to establish and agree on what is fair. This is where the principle of common but differentiated responsibility (CBDR) comes in.

CBDR emerged with the Rio Declaration in 1992, where Principle 7 states that developed countries have a responsibility for the international pursuit of sustainable development which stems from (a) the pressures their place on the global environment, (b) the technologies and (c) financial resources they command. CBDR has since formed the normative backbone of the Kyoto protocol, taking not only account of the technical and financial capabilities but also of the global ecological debt of developed nations, i.e. their historic emissions of greenhouse gasses. This mixture of current capabilities and historic culpability 5 underpins the creation of the three annex categories (developed, post-socialist and developing countries) under the Kyoto agreement. With the explicit recognition of the rights of developing countries to pursue increased access to energy services for their poor (and thus by implication risk an increase in overall emissions), we have four underlying dimensions for CBDR: cumulative historic emissions, current consumption (which could be too high or too low), current financial and technical ability to help others. Furthermore we have seen that at the EU level, national targets for renewable energy have been set on the basis of (amongst others) national capabilities in terms of available renewable energy potential (see, for example, Rowlands, 2005). This brings the number of CBDR dimensions up to five.

So given that international climate policy has produced national emissions reduction targets, what does this mean for the development of renewable energy at the local level? Is there scope for reinterpreting the CBDR principle at the local level in developed countries? It makes no sense to disaggregate cumulative historic fossil fuel consumption below the national level, since the historic locations of heavy industry are now often the less affluent parts of many early industrialising countries (like the UK) who have shifted towards a service economy. Similarly, financial and technical capabilities should not be geographically disaggregated below the national level.

Disaggregating current consumption levels and rights to energy services can open a separate can of worms. The argument for differential entitlement for older people may rest on evidence that they are more likely to suffer ill health as a result of heat waves or cold snaps (e.g. Walker and Day, 2012), and old age raises fewer distributional issues as most people expect to be old one day. A similar argument may also apply to the other end of our life cycle, i.e. to children. For a more geographical disaggregation, we could argue that people living in a cold climate are entitled to use more heating, or that people in a hot humid climate may be entitled to using air conditioning. However 
p. 227. Climate policy and the siting of renewable energy projects; towards common but differentiated responsibility at the community level

the process of allocating differentiated rights to energy across geographical space would be fraught with difficulty, not only because of practical questions of how much is 'fair allocation', but also because existing physical infrastructure and historic energy prices have not developed independently of each other and of geography; e.g. should North Americans be entitled to more transport services given the low density of their urban landscapes, or more heating services because their existing homes are bigger? Perhaps the most reasonable answer to give here is not so much to consider the absolute values of business as usual, but rather to look at the options for a transition towards a less carbon intensive living at the level of communities of place, situated in a particular landscape.

This link between communities and landscape also exist for the final component of CBDR. National emission reduction targets can be divided up between different mitigation options, including different renewable energy technologies. The technology specific targets can then be allocated according to existing resource maps. It is very clear from such maps that resources such as wind, biomass, geothermal etc. are very unevenly distributed across the UK. This uneven geography means that some parts of the country can and should do more than others.

In short, of the five dimensions of 'doing our fair bit' at the national level to reduce the negative impacts of anthropogenic climate change, two can be disaggregated to the level of local landscape within which a community of place resides. These two dimensions, reducing local carbon emissions and accepting or embracing more local production of renewable energy, are interrelated and should not be dealt with in isolation. Together they constitute the local principle of CBDR for anthropogenic climate change. It should be noted that this is conceptually different from the idea(I) of local or regional self-sufficiency. The local principle of CBDR does not consider if you are importing or exporting energy, but if you -as a community in a landscape- are consuming more than a fair share of energy and are producing less than a fair share of renewable energy. I have argued in the past that the benchmark for the former lies with best practice transition examples: that is, communities that were once comparable to yours but have since made a big deliberate transition (van der Horst, 2014). The benchmark for the latter lies with the distribution of renewable energy potential across the country, allowing for a spatial disaggregation of the national target for renewable energy production. As a consequence, it is unavoidable that some areas that in the past were net consumers of energy, will now become net exporters of energy.

\section{Towards a local area based justice framework for siting renewables}

Having identified the two local dimensions of CBDR for climate change mitigation, the question remains as to how we can move to a situation in which local people do not feel as if injustice has been done to them because they may have to contend with more local renewable energy projects than they would prefer.

Let me start with two assertions. The first one is that local people who oppose renewable energy facilities are not acting out of selfish or unethical motivations. Many academics have written to debunk the myth that local opposition stems largely from selfish NIMBYISM (e.g. Burningham, 2000; Wolsink, 2000; Devine-Wright, 2005). Various studies have drawn attention to place-attachment theory, explaining that the development of wind farms or other renewable energy facilities can pose a threat to people's sense of dignity and self-identity (see Devine-Wright, 2013). Whilst it is clearly possible to discern private concerns (e.g. on property prices), local protesters strongly contest the 'selfish' nature of their protest; they tend to see themselves as acting for the common good and seeking to protect their local community. Their concerns are 
p. 228. Climate policy and the siting of renewable energy projects; towards common but differentiated responsibility at the community level

relatively close-to-home in space and time, but that does not make them less legitimate. The observation that rejection of wind farm proposals correlates positively with high voter turn-out at the local level (van der Horst and Toke, 2010) demonstrates that active citizenship and care for the local environment go hand in hand. In short, we need to address the ethical concerns of local opponents to renewables.

The second assertion is that the promotion of renewable energy, as part of a climate policy that seeks to reduce greenhouse gas emissions ${ }^{6}$, is a deeply ethical policy. It is worth reflecting on this. This is a policy that seeks to prevent injustice for people who do not yet exist. Can we think of a more radically ethical (secular) policy in modern history? We are asked to take actions which bring us discomfort, for beneficiaries who are remote abstractions for us. The nearest parallel I can think of, was the campaign for the abolition of slavery. The vast majority of people who were actively opposing slavery, had never seen a slave - the victims of slavery were possibly as alien and remote for them in space as future victims of climate change are alien and remote to us in time. Given this radical nature of climate policy, it is no surprise that its implementation is so fraught with difficulties.

So what kind of justice can help us to reduce and resolve the tensions between these two assertions? The body of scholarly literature addressing questions of justice is immense and all I can do in this short space is to pick and develop a few relevant ideas. The question of justice in siting conflicts over renewable energy facilities is not of a typical distributive nature, since the conflict is not about private goods and services which could be redistributed (the principle of CBDR itself is distributive in nature, but it relates to responsibilities rather than to rights). I am also less inclined to focus here on procedural justice. It is hugely important but I feel it has already been covered extensively and appropriately in existing literature. In recent years much has been written about justice as recognition (for example by Nancy Fraser and David Schlosberg) and I will draw here on one particular contribution, by Frank Haldemann to collective recognition, set in the context of transitional justice. Let me first elaborate on these two aspects.

Why collective? Greenhouse gas emissions are/were caused by many and are/will be inflicting damage on many. Routes of individual causality and victimization (for instance, one-to-one or one-to-several) are hidden by the slow, diffuse, cumulative and indirect nature of the relationship between emissions and impacts. From both a moral and a practical perspective, the temporal delay in victimization means that justice should be sought at a collective rather than an individual level. The moral alternative would be to see carbon debt as a personal inheritance, like a genetic defect that cannot be shaken off by socio-economic mobility or by migration across national borders. The practical consequences of a focus on individual inheritable carbon debts would be too grotesque to contemplate (e.g. the need for paternity tests).

Why transitional justice? Before I argue why I think that climate justice can benefit from some of the ideas of transitional justice, let me briefly look at other notions of doing justice that might have some resonance in the climate justice debate. 7 Preventive justice concerns itself with stopping crimes before they happen, whereas the 'crime' of greenhouse gas emissions is continuous; it can be reduced but not prevented. Restorative justice involves the meeting and communication between victims and offenders; In the case of climate change with its delayed impacts and millions of victims and offenders, restorative justice would require time-travel and mass-to-mass communication tools.

Transitional justice 'refers to the set of judicial and non-judicial measures that have been implemented by different countries in order to redress the legacies of massive human rights abuses. These measures include criminal prosecutions, truth 
p. 229. Climate policy and the siting of renewable energy projects; towards common but differentiated responsibility at the community level

commissions, reparations programs, and various kinds of institutional reforms' (ICTJ, undated). IIOIn the first instance it may seem quite a leap to look at climate justice through the lens of transitional justice ${ }^{8}$, since the latter has largely dealt with historic abuses, whereby some of the surviving victims we able to hold the surviving perpetrators to account. But climate change will over time create far more victims than any historic events where transitional justice has been called upon, and it could be easily argued that the suffering inflicted on these victims can be labeled as human rights abuse: Article 3 of the UN 1948 Universal Declaration of Human Rights proclaims the rights to life, liberty and security of person - which is an essential right to the enjoyment of all other rights. Articles 23-27 proclaim economic, social and cultural rights which include the right to a standard of living adequate for health and wellbeing.

Whilst the overwhelming majority of the suffering will take place in the future, and will often affect people who are not even born yet, the causes of this suffering lie in the past and in the here and now. This spatio-temporal delay between the act of hurting the other, and the suffering experienced by the other, does by no means imply that the experienced injustice is in any way diminished. I would argue that the knowledge of the current causing of future suffering is sufficient ground for initiating a process of transitional justice. And clearly this process would be flawed and incomplete without urgently seeking to discontinue the actions which give rise to future suffering.

The international Centre for Transitional Justice (ICTJ, undated) states that "each transitional justice programme is unique and implemented in a specific societal context, often marked by broken institutions, exhausted resources, diminished security, and a distressed and divided population". This statement illustrates the need for each transitional justice programme to be tailored according to the particular injustice(s) involved. It is not so difficult to envision climate change in the above description, from 'broken institutions' in reference to international climate governance (e.g. the problems of agreeing on the Kyoto protocol, the failure to achieve humble Kyoto targets and the struggle to develop its follow-up), to 'distressed and divided population' in the form of hungry farming communities, victims or flooding or climate refugees (see Bradley, 2012).

There are also interesting specific issues with the application of the idea of transitional justice for climate change. First of all, victims will normally not be able to hold perpetrators to account, because of the time lapse (previous generations of greenhouse gas emitters have passed away), the diffused impacts of greenhouse gas emissions and the multitudes of perpetrators. Secondly perpetrators cannot and should not normally be portrayed as evildoers; the majority of citizens living in more affluent countries are living above their carbon means. What transitional justice could do, is to give us a narrative through which we can make sense, and communicate to others (including future generations) the sacrifices we make to reduce emissions or put up with renewable energy projects, the barriers we face in doing so or the reasons why we feel that certain sacrifices are a bridge too far for us. In other words, at this point in time, transitional justice could serve not as a tool to help reconcile surviving victims with the abuses they have suffered, but more to reconcile everyday perpetrators with the knowledge of the damage they cause to future generations and the extent to which they are (in)sufficiently seeking to reduce that damage. Whilst this process can involve individual soul searching, it should be amalgamated or executed at a more collective level of a community of place within a certain landscape - the scale at which I discussed the options for local CBDR. 
p. 230. Climate policy and the siting of renewable energy projects; towards common but differentiated responsibility at the community level

\section{Words and actions for Collective Transitional Climate Justice}

Frank Haldemann (2008) proposes that we could achieve (transitional) justice through collective recognition which could be actualized through four activities: truth-telling, apologies, reparations and positive symbolism. I will explore these four activities in turn, examining how they might can act as heuristic devices to help resolve the tension between just shorter-term local concerns and the just longer-term global concerns.

The idea of reparations is very similar to existing local payments. As with developers providing 'compensation' or 'community benefits' to local communities, Haldemann's view of reparations is that these serve a symbolic function, rather than actually trying to off-set a physical or measurable loss. Indeed our existing legal system and siting requirements are already quite suited to deal with biophysical impacts. More creatively, we could think of financial resources given to the local community to administer climate justice elsewhere.

Positive symbolism is not as easily defined as reparations as it may include a range of material and institutional interventions. These interventions need to be creative, as symbolism implies a certain degree of visibility and uniqueness; a stand-out thing in the local context, which continues to draw positive attention over a longer time period. A key aspect of ensuring the effectiveness of positive symbolism, is to come up with an idea that holds a particular meaning within the local community and/or sits in a particularly meaningful location in the local landscape. We could think of examples that include environmental art, provide new touristic attractions in the local area, or consist of a redevelopment of industrial heritage sites. More provocatively, we could think of building physical monuments for future generations in explicit recognition of the climate challenges they will be facing due to our greenhouse gas emissions.

Apologies seem to be more relevant for past wrong doings, than for deliberate future actions for the common good which create local impacts. However Haldemann draws attention to victim-centred acknowledgement, whereby those who are negatively affected receive a collective or institutional apology which is focused on the human dignity and legitimate feelings of those affected. So instead of ignoring local impacts on landscape aesthetics and place identity, we should seek to acknowledge explicitly and proactively the local feelings; the definition of losing out can only be drafted by the person who feel they are losing out. One way to address this is to ensure that the decision to site the project is accepted as legitimate by local inhabitants, for example through a democratic process which determines not only the ideas behind renewable energy and the amount to accept locally, but also the ways in which the majority will seek to recognize and alleviate local feelings.

Truth-telling in the context of this paper, clearly needs to be two-sided; the truth about climate change, what causes it and how it is going to affect future generations, including the local community. On the other hand, the truth equally needs to be told and heard about how valuable aspects of the existing community and landscape are for the people who live there and/or who feel they may be negatively affected by the project. It provides a narrative of the sacrifices made, or the limits to the sacrifices people were willing to make. It could be argued that a collective recognition of the values of the local landscape, hinges on events that mobilise this kind of truth telling, i.e. the shared value of the local landscape is 'made' by a captivating story, whether it is art (e.g. landscape paintings, poetry or literature) or architecture (e.g. country estates), old history (e.g. battle fields) or more recent events like a big siting controversy that has exercised the community.

In other words Haldemann's four activities for collective recognition, when applied to local conflicts about actions for climate change mitigation, fall together into two 
p. 231. Climate policy and the siting of renewable energy projects; towards common but differentiated responsibility at the community level

categories of symbolic payments and positive symbolism (actions of recognition), and truth-telling and victim-centred acknowledgement (words of recognition).

\section{Discussion and policy implications}

In this paper I have identified two local principles of CBDR which should underpin climate mitigation policy at the local level in developed countries; local mitigation capabilities in the form of renewable energy potential (benchmarked against a GIS analysis for the whole country), and local emissions culpability in the form of potential emission reductions (benchmarked against best practice examples - which are improving over time). A community of place should contend with both principles, but in the past UK policy did not encourage both principles to be adopted and pursued together at the local level. Renewable energy was largely pursued through the normal development process in which a commercial developer had to select a site and submit a planning permission. This has led to many siting controversies with the local community.

I have subsequently explored four activities which can help mitigate such controversies, by bringing collective recognition to local communities affected by renewable energy facilities siting. These activities are inspired by transitional justice, but with a twist in that we are seeking recognition for (locally unpopular) actions in the context of alleviating far greater future suffering. These activities have policy implications: who should initiate and lead in the process of producing these acts and words of recognition? Given that climate mitigation policy is supposed to serve the (global) common good, and local opposition is also engaged with questions of the (local) common good, it makes sense for recognition to be a process that involves citizens at different levels. In practical policy terms, it would be a national debate about the CBDR principles and how these should be scaled, followed by a local debate about the values of landscape and community, and how these can be aligned with the two local CBDR principles. As a logical consequence, it should be the right and duty of the community to discuss and lead on the local 'fair bit' of fulfilling the national targets for renewable energy. In practical terms it would mean that the community should be able to plan wind farms and invite developers to bid for the contract. Giving local communities the development rights over the wind (and of the view) would enable them to take a much more proactive role. This right might challenge the privileged position of local landowners but it would not be quite such a politicized decision as the community buy-out in the Scottish highlands. ${ }^{9}$ It would not limit the scope for commercial enterprise, but it would put the community in charge of doing their fair local bit for climate change mitigation, both in terms of more renewable production and more sustainable consumption of energy. We could expect to see much more integration and synergetic developments between local production and consumption. It would make for a far less compartementalised and centralized approach to climate change mitigation, it would be much more morally consistent and it would empower and enable active citizen engagement with our energy and climate future - something that has been badly lacking.

The above suggestions may require a radical rethinking of the existing environmental governance model. If we want to have a climate policy that is worthy of the name, then we should acknowledge the radical moral nature of the task and, as transitional justice stipulates, accept (as a starting point) the need to reform our institutions. 
p. 232. Climate policy and the siting of renewable energy projects; towards common but differentiated responsibility at the community level

\section{Notes}

${ }^{1}$ Boyndie wind farm was the first operational joint-ownership project. For an up to date list of operational co-op projects, see www.energy4all.co.uk

2 Some authors talk of 'community compensation' instead, even though it is not always clear what it is that the community needs to be compensated for (e.g. in research on CCS; see Ter Mors et al., 2012)

3 For public opinion see Donald (2014). For the opinions of UK members of parliament, see Benady \& Owens (2014).

4 The question of ownership lies at the heart of this conflict of ideals and especially cooperatives can be a problematic category; they may be seen as private, exclusive and profit driven, even though the latter two aspects depend entirely on the strategy of member recruitment (could be aiming for 'local' and 'representative' members) and the selection of upper and lower limits for share ownership. Some early farmer-led cooperatives in Denmark and Germany had a small number of members making good returns on substantial investment but most members of renewable energy cooperatives are politically motivated to make their small investment.

5 I deliberately use the term 'culpability' here, as it may mean responsibility or accountability (for historic emissions before global warming was understood) as well as blame or guilt (for continued high emissions now that we know about anthropogenic global warming).

${ }^{6}$ State support for renewables is typically presented under multiple labels, like energy security, rural development, export technologies, but as l've argued before, these can usually be better achieved in other ways (van der Horst 2005; van der Horst \& Vermeyen, 2011).

7 For the sake of semantic clarity; the question is how to do justice (e.g. distributional, procedural, preventive, retributive) in order to address a particular thematic area (in)justice (e.g. climate, environment, energy).

8 I looked to see if others have attempted this 'leap' and found an interesting note by Hyvarinen (2013), arguing that whilst transitional justice is still a developing area, it may inspire some useful suggestions for dealing with climate change impacts and that in any case we need radical and controversial ideas to create a successful global response to climate change.

9 In the most radical case we could consider the severance of the wind estate, so that land remains private but the wind becomes a local common (see van der Horst \& Vermeylen, 2011).

*Correspondence address: Dan Van der Horst, Drummond Library, Surgeon's Square, Drummond Street, Edinburgh EH8 9XP. Email: dan.vanderhorst@ed.ac.uk

\section{References}

Adger N. (2001) Scales of governance and environmental justice for adaptation and mitigation of climate change. Journal of International Development, 13, 921-931.

Aitken M. (2010) Wind power and community benefits: Challenges and opportunities. Energy Policy, 38, 6066-6075. 
p. 233. Climate policy and the siting of renewable energy projects; towards common but differentiated responsibility at the community level

BBC (2014) Wind farm shares to be sold to locals under new scheme. BBC News, 3 November 2014. http://www.bbc.co.uk/news/business-29879140

Benady A. and Owens J. (2014) Overwhelming majority of Tory PMs do not accept climate change is man made. PR Week. http://www.prweek.com/article/1311495/overwhelming-majority-tory-mps-notaccept-climate-change-man-made

Bradley E. (2012) Critical Reflection: Forced Migration and Transitional Justice Advancing the Research Agenda. http://www.brookings.edu/research/papers/2012/07/reflection-transitionaldisplacement-bradley

Burningham, K. (2000) Using the language of NIMBY: a topic for research, not an activity for researchers. Local Environment, 5, 1, 55-67.

Cass, N., Walker, G. and Devin-Wright, P (2010) Good Neighbours, Public Relations and Bribes: The Politics and Perceptions of Community Benefit Provision in Renewable Energy Development in the UK. Journal of Environmental Policy and Planning, 12, 3, 255-275.

Dawson A. (2010) Climate Justice: The Emerging Movement against Green Capitalism. South Atlantic Quarterly, 109, 2.

DECC (2014) Community Energy Strategy. Department of Energy and Climate Change, UK.

Devine-Wright P. (2005) Beyond NIMBYism: towards and integrated framework for understanding public perceptions of wind energy. Wind Energy, 8, 125-139.

Devine-Wright P. (2013) Think global, act local? The relevance of place attachments and place identities in a climate changed world. Global Environmental Change, 23, 61-69.

Donald R. (2014) Does British belief in climate change really go up and down? A look at 14 polls. http://www.carbonbrief.org/blog/2014/07/how-much-do-views-onclimate-change-fluctuate-a-look-at-14-polls/

Haggett C., Creamer E., Harnmeijer J., Parsons M., Bomberg E. (2013) Community Energy in Scotland: the Social Factors for Success. Edinburgh Centre of Carbon Innovation.

Haldemann F. (2008) Another kind of justice: Transitional Justice as Recognition. Cornell International Law Journal, 41, 675-737.

Hyvarinen J. (2013) Climate change, transitional justice and loss and damage. http://www.field.org.uk/papers/climate-change-transitional-justice-and-loss-anddamage

ICTJ (undated) What is Transitional Justice? International Centre for Transitional Justice. http://www.ictj.org/about/transitional-justice

Pollit M. G. (2010) UK Renewable Energy Policy since Privatisation. EPRG Working Paper 1002. Cambridge Working Paper in Economics 1007

Ter Mors, E., Terwel, B.W. and Daamen, D.D.L. (2012) The potential of host community compensation in facility siting. International Journal of Greenhouse Gas Control, 11, S130-S138.

Rowlands I.H. (2005) The European directive on renewable electricity: conflicts and compromises. Energy Policy, 33, 8, 965-974.

Shumacher E.F. (1973) Small is Beautiful. http://www.ditext.com/schumacher/small/small.html

Van der Horst D. (2005) UK biomass energy since 1990; the mismatch between project types and policy objectives. Energy Policy, 33, 5, 705-716.

Van der Horst D. (2008) Social enterprise and renewable energy: emerging initiatives and communities of practice. Social Enterprise Journal, 4, 3, 171-185.

Van der Horst D. (2014) Landscapes of lost energy: Counterfactual geographical imaginary for a more sustainable society. Moravian Geographical Reports, 22, 2, 66-72. 
p. 234. Climate policy and the siting of renewable energy projects; towards common but differentiated responsibility at the community level

Van der Horst D. and Toke D. (2010) Exploring the landscape of wind farm developments; local area characteristics and planning process outcomes in rural England. Land Use Policy, 27, 214-221.

Van der Horst D. and Vermeylen S. (2010) Wind theft, spatial planning and international relations. Review of Energy Law and Policy, 1, 67-75.

Van der Horst D. and Vermeylen S. (2011) Rights to landscape in the global moral economy of carbon. Landscape Research, 36, 4, 455-470.

Vermeylen S. (2007) Contextualising 'Fair' and 'Equitable': the San's Reflections on the Hoodia Benefit-Sharing Agreement. Local Environment, 12, 4, 423-436.

Walker G. and Devine-Wright P. (2008) Community Renewable Energy - what should it mean? Energy Policy, 36, 2, 497-500.

Walker G. and Day R. (2012) Fuel Poverty as Injustice: Integrating Distribution, Recognition and Procedure in the Struggle for Affordable Warmth. Energy Policy, $41,69-75$

Wolsink, M. (2000) Wind power and the NIMBY-myth: institutional capacity and the limited significance of public support. Renewable Energy, 21, 49-64. 